\title{
RXF 393
}

National Cancer Institute

\section{Source}

National Cancer Institute. RXF 393. NCI Thesaurus. Code C117215.

A clear cell adenocarcinoma cell line established from a 54 year old male patient with renal cell carcinoma. 